\title{
TINDAKAN ABORSI DI INDONESIA MENURUT HUKUM ISLAM
}

\section{Oleh:}

\section{Sun Choirol Ummah}

MKU UNY

email: sun.ummah@gmail.com

\begin{abstract}
Abstrak: Aborsi dalam bahasa Arab disebut isqatu al-hamli al-ijhad, merupakan tindakan penghentian dini suatu proses alami atau penyakit, pengeluaran hasil konsepsi dari uterus sebelum janin viabel.Secara umum, pengguguran kandungan dapat dibagi menjadi 2 macam, yaitu: pengguguran spontan dan pengguguran buatan atau disengaja.Aborsi spontanadalah pengguguran tidak sengaja yang terjadi tanpa tindakan apapun.Sedangkan aborsi buatan adalah pengguguran yang terjadi sebagai akibat dari suatu tindakan. Aborsi dalam bentuk kedua ini dapat dibedakan dalam 2 macam, yaitu aborsi articialis therapicus dan aborsi procatus criminalis. Aborsi articialis therapicus adalah pengguguran yang dilakukan oleh dokter atas dasar indikasi medis yang dilakukan sebagai penyelamatan terhadap jiwa ibu yang terancam bila kelangsungan kehamilan dipertahankan.Sedangkan aborsi provocatus criminalis adalah pengguguran yang dilakukan tanpa dasar indikasi medis misalnya, aborsi yang dilakukan untuk meniadakan hasil hubungan seks diluar perkawinan atau untuk mengakhiri perkawinan yang tidak dikehendaki.
\end{abstract}

Kata Kunci: Aborsi, Perempuan, Hukum Islam.

\section{Pendahuluan}

Baru-baru ini negeri kita dihebohkan dengan berita bahwasannya di Jakarta Selatan telah ditemukan tempat tindakan aborsi milik ibu Atun yang sudah berpraktek sekitar dua belas tahun, dan baru diekspose secara besar-besaran di media cetak maupun televisi dalam agenda bulan Pebruari 2009. Bila kita amati, sebenarnya berita itu bukanlah merupakan hal yang baru. Kasus aborsi sebagaimana tiupan semilir angin, kasus tersebut selalu ada, namun tidak pernah mengemuka, dan ditangani secara serius.

Data dari WHO menyebutkan, setiap tahun terjadi sekitar 20 juta aborsi tidak aman, dimana menimbulkan kematian 70 ribu perempuan tiap tahunnya. Pada kenyataannya di negara-negara maju, baik karena pelayanan kesehatannya lebih baik maupun telah legalnya aborsi, aborsi tidak aman (Aborsi Provocatus Criminalis) memiliki 100-500 kali lebih beresiko dibanding aborsi aman (Aborsi Provocatus 
Medicinalis). Kematian akibat aborsi ini adalah 1 diantara 3700 aborsi. Sementara untuk negara berkembang, di mana pelayanan kesehata untuk perempuan hamil hanya 50 persennya saja, angka kematian akibat aborsi ini lebih tinggi, satu untuk 250 aborsi. Di seluruh dunia, hampir $75 \%$ negara telah mengijinkan aborsi.

Untuk Indonesia, meski tidak ada angka resmi mengenai kejadian aborsi, tapi hasil pengamatan Budi Utomo cs, diperkirakan dari 100 kehamilan, sebanyak 30 akan berakhir dengan keguguran atau pengguguran. Dari IPPF (International Planed ParenthoodFederation) mengatakan, dari 1000 perempuan ada 32-46 kejadian aborsi. Dan menurut WHO, 15\% dari kehamilan akan berakhir dengan keguguran spontan, maka berarti di Indonesia 15-20 diantara 100 kehamilan diakhiri dengan pengguguran sengaja. Konon di Jakarta saja setiap harinya sekitar 50-70 permintaan pengguguran janin, dan di Surabaya, satu klinik yang dikelola oleh duaorang dokter terungkap, gara-gara praktek mereka diajukan ke pengadilan, antara tahun 1987 hingga pertengahan 1988, terjadi 300 pengguguran janin di klinik tersebut (Sa'abah, 2001: 79-80).

Kajian tentang tindakan aborsi ini bertujuan untuk memahami makna aborsi, pandangan umum tentang tindakan aborsi, dan juga pandangan Hukum Islam terhadap tindakan aborsi. Setelah itu, harapan yang diinginkan selanjutnya adalah selain lebih memahami hal-hal yang diperbolehkan dan dilarang melakukan aborsi, juga diharapkan agar tindakan aborsi tidak lagi dilakukan semena-mena, bila tidak ditemukan alasan yang tepat untuk melakukannya, misalnya untuk menyelamatkan nyawa sang ibu.

\section{Pengertian Aborsi}

Aborsi dari bahasa Inggris yaitu abortion yaitu penghentian dini suatu proses alami atau penyakit, pengeluaran hasil konsepsi dari uterus sebelum janin viabel(Daniel Santana, 2007: 8). Dalam bahasa Arab disebut Isqatu al-Hamli alIjhad. Sedangkan secara terminologis, menurut Sardikin Gina Putra aborsi ialah pengeluaran hasil konsepsi dari rahim sebelum hasil konsepsi dapat lahir secara alamiah dengan adanya kehendak merusak hasil konsepsi tersebut dan menurut Nani Soedo SH, aborsi adalah pengeluaran buah kehamilan pada waktu janin masih sedemikian kecilnya, sehingga janin tidak dapat hidup(Yanggo, 2001: 52).Menurut 
Koesnadi, aborsi adalah pengeluaran buah kehamilan pada waktu janin masih sedemikian kecilnya sehingga tidak dapat hidup di luar rahim, yaitu apabila berat badan janin masih kurang dari 1000 gr atau kehamilannya kurang dari 20 minggu (Koesnadi, 1992: 130).

Dalam masalah aborsi ini, apakah janin itu hidup atau mati, tidak dipersoalkan.Hal ini berarti, bahwa janin yang belum memiliki tanda-tanda kehidupan seperti yang terdapat pada manusia, yaitu ada respirasi pernafasan, sirkulasi (peredaran darah) dan aktifitas otak, termasuk aborsi.Janin yang sudah berusia 16 minggu dapat disamakan dengan manusia karena peredaran darahnya yang merupakan tanda dari kehidupan, telah berfungsi sebagaimana mestinya (Hasan, 1998: 44-45).

\section{Macam-macam Aborsi}

Secara umum, pengguguran kandungan dapat dibagi menjadi 2 macam, yaitu: pengguguran spontan (spontaneous aborsi) dan pengguguran buatan atau disengaja (provocatusaborsi). Aborsi spontan (spontaneous aborsi) adalah pengguguran tidak sengaja yang terjadi tanpa tindakan apapun.Penguguran dalam bentuk ini lebih sering terjadi karena faktor diluar kemampuan menusia, seperti pendarahan (blooding) dan kecelakaan (Dewi, 2008: 78).Dikalangan para ulama, bentuk ini disebut dengan alisqath al-'afw (Yanggo, 2001: 52).

Sedangkan aborsi buatan (provocatusaborsi) adalah pengguguran yang terjadi sebagai akibat dari suatu tindakan. Disini campur tangan manusia tampak jelas. Aborsi dalam bentuk kedua ini dapat dibedakan dalam dua macam, yaitu aborsi articialis therapicus dan aborsi procatuscriminalis. Aborsi articialistherapicus adalah pengguguran yang dilakukan oleh dokter atas dasar indikasi medis. Dalam istilah lain dapat disebutkan sebagai tindakan mengeluarkan janin dari rahim sebelum masa kehamilan. Hal ini dilakukan sebagai penyelamatan terhadap jiwa ibu yang terancam bila kelangsungan kehamilan dipertahankan, karena pemeriksaan medis, menunjukkan gejala seperti itu.Dikalangan fuqaha dan ulama kontemporer, aborsi dalam bentuk ini dikenal dengan istilah al-isqath al-dharuri atau al-ijhadh al'ilaji. 
Aborsi provocatus criminalis adalah pengguguran yang dilakukan tanpa dasar indikasi medis misalnya, aborsi yang dilakukan untuk meniadakan hasil hubungan seks diluar perkawinan atau untuk mengakhiri perkawinan yang tidak dikehendaki. Dalam kalimat lain disebutkan bahwaaborsi provocatus criminalis, dikalangan ulama Islam disebut dengan al-isqth al-ikhtiyari atau al-ijhadh al-ijtima'ie, adalah tindakan mengeluarkan janin dari rahim secara sengaja dan tanpa sebab yang membolehkan atau darurat sebelum kelahiran tiba.

Dalam jenis aborsi provocatus criminalis juga termasuk menstrualregulation (pengaturan menstruasi). Pengaturan menstruasi biasanya dilaksanakan bagi perempuan yang merasa terlambat waktu menstruasi, dan berdasarkan hasil pemeriksaan laboratoris ternyata positif dan mulai mengandung. Dalam keadaan demikian perempuan yang terlambat mentruasinya meminta kepada dokter untuk “membereskan” janinnya (Yanggo dan Hafiz Anshary, 1994: 116-117).

\section{Faktor-faktor Pendorong Orang Melakukan Aborsi}

Kendatipun ada larangan aborsi yang diancam dengan pidana, karena merupakan kejahatan, tetapi hal itu tidak membuat para perempuan, merasa gentar untuk melakukan aborsi, apakah yang melakukan itu para ibu, ataupun para remaja putri.

Dalam garis besarnya ada dua macam alasan orang melakukan aborsi: 1) atas dasar indikasi medis, seperti: a) untuk menyelamatkan ibu, karena apabila kelanjutan kehamilan dipertahankan, dapat mengancam dan membahayakan jiwa si ibu, b) untuk menghindarkan kemungkinan terjadi cacat jasmani atau rohani, apabila janin dilanjutkan, 2) atas dasar indikasi sosial, seperti: a) karena kegagalan mereka dalam menggunakan alat kontrasepsi atau dalam usaha mencegah terjadi kehamilan, b) karena mereka sudah menemukan dokter yang bersedia membantu melakukan pengguguran, c) karena kehamilan yang terjadi akibat hubungan gelap dan ingin menutup aib, seperti yang dilakukan oleh perempuan yang belum bersuami (gadis atau janda) atau dilakukan oleh perempuan yang telah bersuami dengan laki-laki lain karena terdorong oleh godaan dan kenikmatan sekejap, d) karena kesulitan ekonomi yang membelit bagi sebagian orang, sedangkan kehamilan itu tidak diinginkan, yang terjadi di luar dugaan, e) karena kehamilan yang terjadi akibat perkosaan. 
Kendatipun kejadian itu di luar kehendaknya dan dia tidak dapat dipersalahkan, tetapi rasa malu tetap ada apabila terjadi kehamilan (Hasan, 1998: 48-49).

Pada umumnya perempuan melakukan aborsi provocatus criminalis karena didorong oleh beberapa hal, diantaranya: pertama, dorongan individual, ini meliputi kekawatiran terhadap kefakiran, tidak ingin mempunyai keluarga besar, memelihara kecantikan, mempertahankan status perempuan karier dan sebagainya, kedua, dorongan kecantikan, dorongan ini timbul biasanya bila ada kekhawatiran bahwa janin dalam kandungan akan lahir dalam keadaan cacat. Kekhawatiran ini timbul disebabkan oleh pengaruh radiasi, obat-obatan, keracunanan sebagainya, ketiga,dorongan moral. Dorongan ini timbul biasanya karena perempuan yang mengandung janin tidak sanggup menerima sanksi sosial dari masyarakat, disebabkan hubungan biologis yang tidak memperhatikan moral dan agama. Seperti kumpul kebo atau kehamilan diluar nikah (Yanggo dan Hafiz Anshary,1994: 116117).

Selain itu, Marzuki Umar Sa'abah mengutip pendapat dari Ahmad Anees bahwa, yang menyedihkan adalah bila pengguguran kandungan dilakukankarena semata-mata menolak satu jenis kelamin tertentu.Ada juga pelayanan klinik yang menyebutkan "Klinik Eugenetik" mencoba memberikan pelayanan penelitian pada janin apakah janin itu membawa penyakit keturunan tertentu (syndrome down) (Sa'abah, 2001: 87).

Beberapa alasan seseorang melakukan aborsi antara lain: 1) terdorong oleh politik pemerintah dalam pembatasan penduduk (contoh Cina), 2) pemilihan jenis kelamin, 3) program mewujudkan generasi unggulan, 4) karena mengidap satu penyakit, atau disebut alasan eugenic, 5) karena tidak sahnya si anak, 6) kegagalan kontrasepsi, 7) karena khawatir karier atau pola hidupnya terganggu dengan kemunculan anak, 8) tekanan ekonomi atau beban pemenuhan pendidikan dan kasih sayang, karena pemerkosaan (Sa'abah, 2001: 87).

\section{Cara Pelaksanaan Aborsi}

Untuk melakukan aborsi banyak cara yang ditempuh, diantaranya dengan menggunakan jasa ahli medis di rumah sakit. Cara seperti ini pada umumnya dilakukan oleh para dokter yang hidup dinegara yang mengijinkan pengguguran.Ada 
juga yang menggunakan jasa dukun bayi, terutama didaerah pedesaan dan menggunakan obat-obatan tradisional seperti jamu.Pemanfaatan obat-obatan itu adakalanya dengan ditelan melalui mulut, atau diletakkan ke dalam vagina (alat kelamin perempuan).

Pengguguran yang dilakukan secara medis dirumah sakit, biasanya menggunakan metode sebagai berikut: (1) Curttage dan Dilatage (C \& D), (2) dengan alat khusus mulut rahim dilebarkan, kemudian janin dikiret dengan alat seperti sendok kecil, (3) aspirasi, yaitu penyedotan isi rahim dengan pompa kecil, (4) hysterotomi (melalui operasi).

Adapun cara yang ditempuh oleh para dukun-dukun, tidak memperhitungkan keselamatan si perempuan itu, seperti memijat perut atau pinggul dengan cara paksa untuk mengeluarkanjanin, sehingga terjadilah pendarahan yang bisa berakibat kepada kematian. Malahan ada perempuan karena merasa putus asa, menggugurkan kandungannya tanpa memikirkan resikonya (Hasan, 1998: 46).

Apabila seorang perempuan telah bertekad memutuskan untuk melakukan aborsi, maka faktor usia kandungan adalah amat menentukan. Pengguguran kandungan memang bisa saja dikerjakan sebelum mencapai usia 28 minggu. Namun seringkali pengguguran itu harus dijalankan tidak melebihi dari minggu ke-12 dari usia janin itu, sedangkan setelah usia minggu yang ke-20 sanganlah jarang. Mengenai metode aborsi, Ahmad Anees menjelaskan:

"kehamilan muda, yang tidak dapat dikonfirmasikan dengan pemeriksaan panggul rutin, dapat digugurkan melalui aspirasi endometrial. Dalam prosedur itu, sebuah cannula elastis dimasukkan kedalam rahim untuk menyedot keluar lapisan rahim bersama dengan sebagian kecil dari jaringan-jaringan ari-ari dan janin. Dengan kekosongan rahim pada kehamilan muda pada dasarnya merupakan prosedur yang sama kecuali bahwa cara itu dilakukan setelah kehamilan dikonfirmasikan melalui pemeriksaan pinggul”.

Dalam fase kehamilan selanjutnya ada kasus-kasus tertentu mungkin harus melebarkan leher rahim untuk menarik jaringan janin. Biasanya, cannula plastik atau logam yang lebih besar digunakan untuk tujuan ini. Penggunaan kuret secara terbatas mungkin juga dilakukan setelah aspirasi vakum. Teknik ini digunakan dalam 80 persen upaya pengguguran kandungan sampai usia kehamilan mencapai 12 minggu.

Pelebaran dan kuret yang umumnya dikenal sebagai $\mathrm{C} \& \mathrm{D}$ (Curretage\&Dilation), adalah suatu prosedur ginekologis standar yang 
membutuhkan pembiusan umum. Sebelum aspirasi vakum atau variasi-variasi yang lain dalam upaya itu menjadi populer, C \& D secara rutin dilakukan dalam pengguguran kandungan triwulan pertama. Cara itu masih digunakn sebagai sarana diagnostik dan untuk menanggulangi pendarahan vagina yang banyak. Penyempurnaan lebih jauh atas cara C \& D adalah dengan pelebaran dan pemasangan dan pengosongan (dilation dan evacuation). Dalam kasus ini, pelebaran dilindungi dengan penempatan batang-batang hydrophilic laminaria kedalam leher rahim yang diikuti dengan penggunaan gunting-gunting sedotan vakum kuret untuk memusnakan jaringan janin ari-ari dan lapisan rahim.

Untuk memasukkannya, konsentrasi solusi garam disuntikan ke dalam kantung amniotik yang mengakibatkan kontraksi-kontraksi rahim dan keluarnya janin secara paksa. Metode ini tidak dapat digunakan pada kehamilan yang umurnya kurang dari 6 minggu. Untuk menggantikan solusi saline hyportonic, dapat disuntikan prostaglandin F2a, yang dapat lebih cepat menimbulkan kontraksi.

Begitu pula, sebagai suatu teknik pengguguran kandungan yang masih relatif masih baru, supositoria prostaglandin dapat dimasukkan dalam vagina. Tetapi hal itu dilakukan dalam kasusu-kasus dimana janin telah mati dan sang ibu tidak dapat mengejan untuk melahirkan janin.

Solusi terakhir untuk kehamilan tua yang menjadi masalah adalah pembedahandan pengangkatan janin dan ari-ari hysterotomy.

RU-486, hanya mendatangkan hasil pada 2 bulan pertama kehamilan. Karena itu ia menyebabkan keguguran pada awal proses keguguran. Karena itu ia menyebabkan keguguran pada awal proses kehamilan, sebelum menetasnya telur yang telah dibuahi didalam rahim, hal itu tidak dianggap sebagai pengguguran kandungan oleh hampir semua orang yang melakukannya. Dilain pihak trauma psikologis yang menyertai pembinaan RU-486 mungkin berbeda dalam arti bahwa perempuan itu akan melihat sendiri keluarnya janin dan darahnya jika dibandingkan dengan tehnik-tehnik invasif, dibawah pengaruh obat bius, yang menjadi tak sadar akan kejadian-kejadian yang menimpa tubuhnya (Sa'abah, 2001: 82-83).

Ekstraksi Menstruasi, merupakan metode aborsi tahap dini yang sering digunakan oleh para perempuan di Amerika Serikat untuk memancing haid. Dapat diperoleh pada NHS di daerah tertentu dan sangat mirip dengan aspirasi vakum, 
kecuali bahwa dilakukan hanya sampai kehamilan minggu ke tujuh. Teknik ini tidak menggunakan penyedotan yang kuat seperti aspirasi vakum, tetapi kadang-kadang disebut juga sebagai teknik penyedotan mini. Dokter akan menyuntikkan anestesi lokal ke serviks kemudian mengeluarkan isi rahim melalui jarum yang dipasang pada rahim melalui serviks.

Ekstraksi menstruasi biasa dilakukan pada unit rawat jalan. Seorang perawat dapat diminta memegang tangan anda dan berbicara dengan anda untuk mendapat ketenangan selama prosedur tersebut dilakukan, yang umumnya hanya membutuhkan waktu beberapa menit saja. Sebagian besar perempuan sudah dapat pulang beberapa jam setelah aborsi. Kekurangan utama dari teknik ini yang belum tersebar luas, adalah bahwa kehamilan dapat terlewatkan. Beberapa orang merasa bahwa resiko aborsi ulang lebih berbahaya dan karena itu lebih suka menunggu untuk aspirasi vakum. Resikonya sekitar $1 \%$.

Pesari prostaglandin, ini merupakan metode aborsi dini yang lain yang masih dalam pengawasan di beberapa tempat di Inggris. Meliputi dimasukkannya prostaglandin ke vagina, yang merangsang kontraksi rahim dan membesarkan serviks sehingga isi rahim keluar. Kadang-kadang prostaglandin menimbulkan kejang yang hebat atau diare dan muntah. Semua teknik di atas ini tidak selalu berhasil. Jdi beberapa perempuan pada akhirnya tetap saja harus menjalani prosedur D dan $\mathrm{K}$ (Frater,\& Cetherine Wright, 1991: 90-91).

\section{Akibat Pelaksanaan Aborsi}

Pada pembahasan di atas telah dijelaskan bahwa pengguguran adakalanya dilakukan dengan bantuan ahli medis, dukun, atau dilakukan sendiri. Pengguguran yang dilakukan oleh bukan ahlinya dan tidak memenuhi persyaratan medis lebih banyak menimbulkan akibat negatif yang dapat menimbulkan komplikasi atau kematian.

Berikut ini dikemukakan beberapa kasus hasil penelitian di Amerika Latin, yang dikumpulkan Erik Eckholm: 1) statistik di rumah sakit El-Salvador menunjukkan bahwa 24\% dari angka kematian di rumah sakit tersebut akibat pengguguran tidak sah, 2) selama tahun 1980-an, separuh dari kematian yang ada hubunganya dengan 
kelahiran di Santiago (Chili) adalah akibat pengguguran tidak sah, 3) pada tahun 1964, sebuah penelitian di Cali (Kolumbia) menemukan bahwa kompilasi akibat pengguguran adalah faktor utama yang menyebabkan kematian di kalangan kaum perempuan yang berumur 15-35 tahun, 4) di California tahun 1960-an, sebelun undang-undang pengguguran disahkan, komplikasi yang timbuk dari pengguguran tidak sah menyebabkan satu dari lima kematian yang berhubungan dengan kelahiran, dan ini umumnya terjadi di kalangan perempuan berpenghasilan rendah.

Kasus-kasus di atas bukan berarti bahwa pengguguran yang dilakukan ahli medis tidak menimbulkan akibat atau komplikasi, tetapi hanya untuk menunjukkan bahwa komplikasi yang di timbulkan oleh pengguran yang dilakukan oleh ahli medis lebih besar dari yang ditimbulkan oleh pengguguran yang dilakukan ahlinya.

Diantara akibat yang ditimbulkan oleh pengguguran yang dilakukan ahli medis adalah: 1) gangguan psikis (al-shadmat al-'asabiyah). Ini dapat terjadi ketika alat untuk memeperlebar mulut rahim (uterus) dimasukkan, atau setelah tembusnya vagina dan dinding rahim.Kadang-kadang terjadi setelah cairan hidrolik yang berbeda dimasukkan, 2) pendarahan (blooding) sebagai akibat dari penggunaan obatobatan dan alat-alat. Inilah diantara akibat dan komplikasi yang timbul dari usaha pengguguran, dan tidak sedikit yang menimbulkan kematian (Yanggo dan Hafiz Anshary,1994: 118-119).

Alasan untuk melakukan aborsi medis nampaknya dapat diterima oleh banyak pihak karena tujuanya adalah menyelamatkan salah satu nyawa. Namun pertanyaan yang muncul adalah atas hak apa seorang dokter bisa menentukan mana yang berhak hidup dan mana yang tidak?

\section{Hukum Aborsi}

Dalam kitab Undang-undang Hukum Pidana (KUHP) Indonesia, negara melarang aborsi dan sanksi hukumanya cukup berat. Bahkan hukumnya tidak hanya ditujukan kepada perempuan yang bersangkutan, tetapi semua orang yang terlibat dalam kejahatan itu dapat dituntut, seperti dokter, dukun bayi, tukang obat yang mengobati, atau yang menyuruh, atau yang membantu, atau yang melakukanya sendiri (Hasan, 1998: 51). 
Pasal-pasal dalam KUHP yang menerangkan tentang aborsi: 1) KUHP Pasal 299: Ancaman yang ditujukan terhadap pihak-pihak yang memberi harapan untuk melakukan aborsi dengan ancaman hukuman empat tahun penjara atau denda paling banyak empat puluh lima ribu rupiah (Hamzah, 1986: 151), 2) KUHP Pasal 346: Ancaman yang ditujukan kepada si ibu dengan ancaman hukuman empat tahun penjara, 3) KUHP Pasal 347: Ancaman yang ditujukan terhadap orang lain yang melakukan aborsi tanpa seizin si ibu dengan ancaman hukuman dua belas tahun penjara dan hukuman lima belas tahun penjara bila si ibu meninggal, 4) KUHP Pasal 348: Ancaman yang ditujukan terhadap orang lain yang dilakukan dengan izin si ibu dengan ancaman hukuman lima tahun enam bulan, dan hukuman tujuh tahun penjara bila si ibu meninggal, 5) KUHP Pasal 349: Ancaman yang di tujukan terhadap staf medis atau farmasi yang melakukan aborsi dengan pidana yang ditentukan dalam pasal di atas,dapat ditambah dengan sepertiga dan dapat dicabut haknya (Hamzah, 1986: 168).

Menurut Undang-Undang Kesehatan tentang aborsi Pasal 15 ayat 1 dikatakan "Dalam keadaan darurat sebagai upaya untuk menyelamatkan jiwa ibu hamil dan atau janinya, dapat dilakukan tindakan medis tertentu." Ini merupakan legalisasi aborsi dengan alasan medis (Sa'abah, 2001: 86).

Para Fuqaha (ahli Hukum Islam) telah sepakat mengatakan, bahwa pengguguran kandungan (aborsi) sesudah ditiupkan ruh adalah haram, tidak boleh dilakukan, karena perbuatan tersebut merupakan kejahatan terhadap nyawa, oleh karena itu diwajibkan kepada pelakunya untuk membayar diyat jika janin keluar dalam keadaan hidup dan membayar gurrah jika ia keluar dalam keadaan mati. Gurrah adalah membayar seorang budak laki-laki atau perempuan atau yang dapat menggantikanya. Penguguran kandungan pada masa perkembangan kandungan, merupakan jinayah (tindak pidana), makin meningkat perkembangan kandungan, makin meningkat pula jinayahnya dan paling besar jinayahnya adalah sesudah lahirnya kandungan dalam keadaan hidup (Sa'abah, 2001:53-54). Tampaknya kesepakatan ini lebih menunjuk pada abortus provocatus criminalis (al-Isqat alIkhtiari).

Tetapi apabilaaborsi dilakukan sebelum diberi ruh atau nyawa pada janin itu, yaitu sebelum berumur empat bulan, ada beberapa pendapat.Pertama, golongan yang 
mengharamkan pengguguran pada setiap tahap-tahap pertumbuhan janin sebelum diberi nyawa (al-nuthfat, alaqat dan al-mudhghat).Pendapat ini dikemukakan sebagian ulama Hanafiah, sebagian ulama Malikiah, Imam al-Ghazali, dan Ibn alJauzi. Mereka mengemukakan beberapa hadis sebagai alasan (dalil) untuk menguatkan pendapatnya, diantaranya adalah: 1) Sabda Rasulullah Saw:

Artinya: "Sesungguhnya Allah Swt bila ingin menciptakan manusia (al-'abd), Ia mempertemukan antara laki-laki dan perempuan yang kemudian akan memancar sperma ke setiap pembuluh dan anggotanya. Jika sudah sampai pada hari ketujuh, Allah Swt. menghimpunnya lalu mendatangkan pada setiap pembuluhnya, kecuali penciptaan Adam.(HR. al-Thabrani).

Hadis ini menunjukkan bahwa tahap penciptaan dan pembentukan manusia dimulai pada sperma (al-nuthfat). Kalau pembentukan sudah dimulai pada tahap ini,maka menggugurkan sperma adalah suatu halyang tidak dibolehkan.2) Sabda Rasulullah Saw yang menunjukkan bahwa Allah Swt. menghimpun penciptaanjanin dalam rahim ibunya, yang berupa cairan sperma dalam keadaan tersembunyi. Karena penciptaan itu sudah dimulai pada sperma, maka ia tidak dianiaya dan tidak digugurkan.

Kedua, golongan yang membolehkan pengguguran pada salah satu tahap dan melarang pada tahap-tahap yang lain. Atau melarang pada salah satu tahap dan membolehkan pada tahap-tahap yang lainnya. Secara lebih rinci dapat dikemukakan sebagai berikut: 1) makruh pada tahap al-nuthfat dan haram pada tahap al-alaqat dan al-mudhghat. Ini adalah pendapat Malikiyah, dan dalam madzab Syafi'iyah disebut sebagai makruh tanzih, dengan syarat pengguguran itu atas izin suami.2) boleh pada tahap al-nuthfat, dan haram pada tahap alaqat serta al-mudhghat, 3) boleh pada tahap al-nuthfat dan alaqat, tetapi haram pada tahapal-mudhghat.

Ketiga, golongan yang membolehkan pengguguran pada setiap tahap dari tahap-tahap sebelum pemberian nyawa (al-nuthfat, alaqat dan al-mudhghat). Ini adalah pendapat yang kuat di kalangan ulama Hanafiyah. Mereka mengemukakan beberapa alasan: 1) setiap yang belum diberi nyawa tidak akan dibangkitkan Allah pada hari kiamat. Setiap yang tidak dibangkitkan berarti keberadaannya tidak diperhitungkan. Dengan demikian tidak ada larangan untuk menggugurkannya. 2) janin sebelum diberi nyawa tidak tergolong sebagai manusia. Maka tidak ada 
larangan baginya, yang berarti boleh digugurkan (Yanggo dan Hafiz Anshary, 1994: 126-127).

Jumhur ulama madzab Hanafiyah, Malikiyah, Syafi'iyah, dan Hanabilah, termasuk yang melarang pengguguran pada setiap tahap pertumbuhan janin dalam abortus provocatus criminalis (al-Isqat al-Ikhtiari)yaitu: a) Muhammad Ramli dalam kitab an-Nihayah, membolehkan aborsi dengan alasan belum bernyawa, b) ada pula ulama yang memandangnya makruh, dengan alasan karena janin sedang mengalami pertumbuhan, c) Ibnu Hajar dalam kitabnya at-Tuhfah dan al-Ghazali dalam kitabnya Ihya' Ulumuddin mengharamkan aborsi pada tahap ini (belum bernyawa), dan ulama-ulama kontemporer, seperti Mahmud Syaltut dan Yusuf Qardhawi menyatakan, bahwa sejak bertemu sel sperma dengan ovum (sel telur), maka pengguguran adalah suatu kejahatan dan haram hukumnya, sekalipun si janin belum diberi nyawa, sebab sudah ada kehidupan pada kandungan yang sedang mengalami pertumbuhan dan persiapan untuk menjadi manusia.Tetapi apabila aborsi dilakukan karena benar-benar terpaksa demi menyelamatkan si ibu, maka Islam membolehkan, karena Islam mempunyai prinsip:“ Menempuhsalah satu tindakan yang lebih ringan dari dua hal yang berbahaya, itu wajib (hukumnya)"(Hasan, 1998: 52).

Memperhatikan dan membandingkan antara hukum Islam dan KUHP mengenai aborsi, tampaklah kelemahan dan kekakuan KUHP. Di pihak lain tampaklah keluwesan hukum Islam, yang prinsip-prinsip dasarnya termuat dalam al-Quran dan Hadis, kemudian diistimbathkan oleh para fuqaha menjadi hukum praktis.

\section{Cara Pencegahan Tindakan Aborsi}

Uraian mengenai aborsi dan permasalahannya belum lengkap jika tidak diberikan alternatif menyangkut cara penanganannya. Secara umum, ada dua cara yang dapat dilakukan untuk mencegah terjadinya praktek aborsi. Pertama, melalui upaya hukum (tindakan konstitusional).Cara ini dapat dilaksanakan denganmengeluarkan Undang-undang mengenai aborsi.Mengingat di Indonesia aborsi sudah diatur dalam KUHP, maka upaya yang perlu dilakukan adalah menyadarkan masyarakat Indonesia untuk menjadi masyarakat yang sadar hukum.Ini dapat diusahakan dengan memberi bimbingan dan penyuluhan hukum kepada 
masyarakat luas, yang dilakukan oleh badan penegak hukum atau instansi terkait lainnya.

Kedua, melalui gerakan sosial keagamaan. Dalam hal ini peran para ulama dan para da'i sangat berpengaruh, terutama bagi umat Islam. Mereka dapat menyadarkan umat untuk tidak melakukan perbuatan keji dan tindak kejahatan yang kejam, karena tindakan itu tidak hanya mendapat sanksi hukum di dunia, tetapi di akhirat kelak akan mendapat ganjaran dari Allah Swt.

\section{Penutup}

Dari uraian di atas dapat diambil beberapa kesimpulan, antara lain: 1) Abortus merupakan perbuatan untuk mengakhiri kehamilan dengan mengeluarkan janin dari kandungan, 2) Islam melarang pengguguran kandungan abortus provocatus criminalis (al-Isqat al-Ikhtiari), baik digunakan pada janin yang belum bernyawa ataupun sesudah bernyawa, 3) aborsi merupakan suatu kejahatan dan perbuatan dosa, 4) Islam tidak menutup sama sekali kemungkinan pembolehan aborsi, Islam membolehkan pengguguran dalam keadaan darurat, misalnya bila kehamilan itu dipertahankan maka jiwa ibu akan terancam. Dalam hal ini jiwa ibu lebih diutamakan daripada janinnya, 5) hukum bagi pelaku aborsi adalah membayar denda (ghurrah) atau kurungan menurut tingkat kejahatannya. 


\section{Daftar Pustaka}

Athar, Shahid. 2003. Bimbingan Seks bagi Remaja Muslim.Jakarta: Pustaka Zahra.

Dewi, Alexandra Indrianti. 2008. Etika dan Hukum Kesehatan. Yogyakarta: Pustaka Book Publisher.

Frater, Alison \& Cetherine Wright. 1991. Dilema Aborsi.terj. Lilian Yowono, Jakarta: Arcan.

Hamzah, Andi. 1986. KUHP Kitab Undang-undang Hukum Pidana yang Telah Disesuaikan dengan Undang-undang Baru.Jakarta: Ghalia Indonesia.

Hasan, M. Ali. 1998. Masail Fiqhiyah al-Haditsah.Jakarta: Raja Grafindo Persada.

Higgins, Gregory C. 2006. Dilema Moral Zaman Ini: di Pihak Manakah Anda? Yogyakarta: Kanisius.

Koesnadi. 1992. Seksualitas dan Alat Kontrasepsi.Surabaya: Usaha Nasional.

Qardhawi, Yusuf. 2000. .Halal dan Haram.Jakarta: Rabbani Press.

Sa'abah,Marzuki Umar. 2001. PerilakuSeks Menyimpang dan Seksualitas Kontemporer Umat Islam, Yogyakarta: UII Press.

Santana, Daniel. 2007. Kamus Lengkap Kedokteran.Jakarta: Mega Aksara.

Yanggo, Huzaemah T. dan Hafiz Anshary. 1994. Problematika Hukum Islam Kontemporer.Jakarta: LSIK.

Yanggo, Huzaimah T. 2001. Fiqih Perempuan Kontemporer.Jakarta: Al-Mawardi Prima. 